\title{
Comparison of Cardiopulmonary Function Changes during Wheelchair Propulsion: Backrest Angle
}

\author{
Soo-Young Chae, OT, ATP, $\mathrm{PhD}^{1)}$ \\ 1) Department of Occupational Therapy, College of Health and Welfare, Kyungwoon University: 730 \\ Kangdongro, Sandong-myeon, Gumi, Gyeongbuk, 730-739, Republic of Korea. TEL: +82 10-3071- \\ 2929,Email: robin3938@daum.net
}

\begin{abstract}
Purpose] Changes in cardiopulmonary function during wheelchair propulsion on a treadmill were measured using wheelchairs according to backrest angle adjustment. [Methods] Twenty-two healthy male subjects were the subjects. Oxygen consumption $\left(\mathrm{VO}_{2}, \mathrm{ml} / \mathrm{min}\right)$, heart rate $(\mathrm{HR}$, beats $/ \mathrm{min})$, carbon dioxide emissions $\left(\mathrm{VCO}_{2}, \mathrm{ml} /\right.$ $\mathrm{min}$ ), oxygen uptake per body weight $\left(\mathrm{VO}_{2}, \mathrm{ml} / \mathrm{kg} / \mathrm{min}\right)$, and respiration frequency (Rf) were used as the measurement variables for cardiopulmonary data. [Results] The peak value, average value and value at rest were compared. When resting, the value did not differ except for $\mathrm{VO}_{2}$, and the peak value, did not differ except for $\mathrm{VCO}_{2}$. However, the average value in all except $\mathrm{VO}_{2} / \mathrm{kg}$ (at 13 degrees) was significantly lower than 3 degrees $\left(93^{\circ}\right)$. [Conclusion] A $13^{\circ}$ wheelchair backrest angle $\left(103^{\circ}\right)$ provides a lower cardiopulmonary workload than the base angle $\left(3^{\circ}\right)$. A training program for good seating and posture needs to be provided

Key words: Cardiopulmonary exercise testing, Wheelchair propulsion, Backrest angle
\end{abstract}

(This article was submitted Oct. 28, 2011, and was accepted Nov. 29, 2011)

\section{INTRODUCTION}

Most wheelchair users, including those with spinal cord injuries, have limited use of their legs and must use their upper extremities to propel the wheelchair T. Theoretically, the increase in gas exchange and metabolic rate caused by the interaction of the primary cardiovascular and respiratory systems, in order to replenish the oxygen extracted from the blood, must be spread to the motor muscles. To carry oxygen to the muscles, cardiac output and pulmonary circulation must be increased, and peripheral vasodilatation done properly. At this point oxygen uptake $\left(\mathrm{VO}_{2}\right)$ in muscle oxygen is equal to the oxygen utilization ratio and ventilation is increased in response to the reaction of carbon dioxide $\left(\mathrm{VCO}_{2}\right)^{2}$. However, objective measurement of whose physical fitness is impossible . There have been numerous studies on the effects of gender and age using static evaluations of cardiopulmonary response $\$$ using a treadmill, bicycle ergometer, wheelchair ergometer exercises or arm ergometerf. However, there has been little research on the cardiopulmonary function of wheelchair propulsion according to time and backrest angle, especially research that includes sitting in a wheelchair.

The purpose of this study was to evaluate the cardiopulmonary response of adult male subjects during wheelchair propulsion at different backrest angles and compare the change in oxygen uptake $\left(\mathrm{VO}_{2}\right)$, respiratory frequency (Rf), heart rate (HR), carbon dioxide emissions $\left(\mathrm{VCO}_{2}\right)$ and oxygen uptake per body weight $\left(\mathrm{VO}_{2} / \mathrm{kg}\right)$.

\section{METHODS}

The subjects were twenty-two healthy young men with a mean age of $22.2 \pm 1.7$ years, a mean height of $174.5 \pm 5.3 \mathrm{~cm}$, a mean body weight of $67.6 \pm 10.5 \mathrm{~kg}$ and a mean body-mass index of $22.2 \pm 2.8$. All of them provided their informed consent (Table 1).

In the procedure, a wheelchair treadmill was used for wheelchair propulsion in the sitting position. The measured cardiopulmonary variables were oxygen consumption $\left(\mathrm{VO}_{2}, \mathrm{ml} / \mathrm{min}\right)$, heart rate (HR, beats/min), carbon dioxide emissions $\left(\mathrm{VCO}_{2}, \mathrm{ml} / \mathrm{min}\right)$, oxygen uptake per body weight $\left(\mathrm{VO}_{2}, \mathrm{ml} / \mathrm{kg} / \mathrm{min}\right)$, and respiration frequency (Rf). The measurement variables were measured using the breath-bybreath method.

Participants pushed the wheelchair at the basic backrest angle of $3^{\circ}\left(93^{\circ}\right)$ and $13^{\circ}\left(103^{\circ}\right)$ of backrest angle and rested for several minutes before the test (Figs. 1, 2). The lowest values of $\mathrm{Rf}, \mathrm{VO}_{2}, \mathrm{VCO}_{2}, \mathrm{VO}_{2} / \mathrm{kg}, \mathrm{HR}$ during the rest period were recorded. Thus, each participant acted as

Table 1. Characteristics of the subjects

\begin{tabular}{lllll}
\hline & Age (yrs) & Height $(\mathrm{cm})$ & Weight $(\mathrm{kg})$ & BMI $\left(\mathrm{kg} \cdot \mathrm{m}^{-2}\right)$ \\
\hline Male $(\mathrm{n}=22)$ & $22.2 \pm 1.7$ & $174.5 \pm 5.3$ & $67.6 \pm 10.5$ & $22.2 \pm 2.8$ \\
\hline
\end{tabular}

Mean SD, BMI; Body Mass Index 


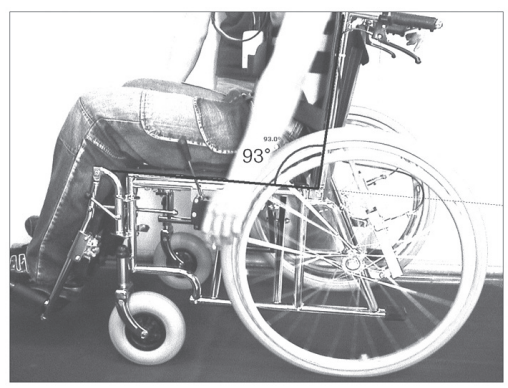

Fig. 1. Wheelchair propulsion at 3 degrees of backrest angle

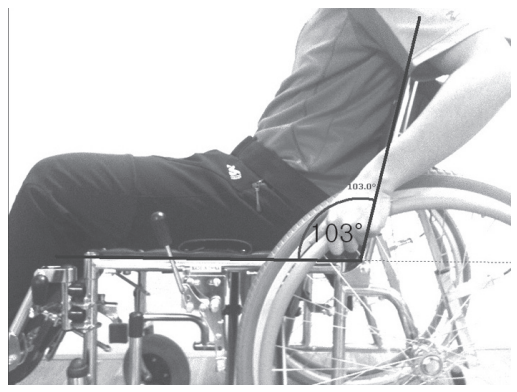

Fig. 2. Wheelchair propulsion at 13 degrees of backrest angle

Table 2. Comparison of physiological responses between the two backrest angles in the resting period

\begin{tabular}{llllll}
\hline angle & $\begin{array}{l}\mathrm{R} \\
(\mathrm{f} / \mathrm{min})\end{array}$ & $\begin{array}{l}\mathrm{Vo} 2 \\
(\mathrm{ml} / \mathrm{min})\end{array}$ & $\begin{array}{l}\mathrm{Vco} 2 \\
(\mathrm{ml} / \mathrm{min})\end{array}$ & $\begin{array}{l}\mathrm{Vo} 2 / \mathrm{kg} \\
(\mathrm{ml} / \mathrm{kg} / \mathrm{min})\end{array}$ & $\begin{array}{l}\mathrm{HR} \\
(\mathrm{bpm})\end{array}$ \\
\hline $3^{\circ}$ & $18.9 \pm 3.2$ & $252.9 \pm 51.5$ & $311.2 \pm 81.7$ & $3.8 \pm 0.6$ & $76.3 \pm 10.6$ \\
$13^{\circ}$ & $20.3 \pm 4.5$ & $281.5 \pm 73.5^{*}$ & $350.2 \pm 146.0$ & $4.1 \pm 0.8^{*}$ & $77.7 \pm 13.4$ \\
\hline${ }^{*} \mathrm{p}<0.05$ & & & & &
\end{tabular}

Table 3. Comparison of physiological responses between the two backrest angles during maximal exercise

\begin{tabular}{llllll}
\hline angle & $\begin{array}{l}\text { Peak R } \\
(\mathrm{f} / \mathrm{min})\end{array}$ & $\begin{array}{l}\text { Peak Vo2 } \\
(\mathrm{ml} / \mathrm{min})\end{array}$ & $\begin{array}{l}\text { Peak Vco2 } \\
(\mathrm{ml} / \mathrm{min})\end{array}$ & $\begin{array}{l}\text { Peak Vo2/kg } \\
(\mathrm{ml} / \mathrm{kg} / \mathrm{min})\end{array}$ & $\begin{array}{l}\text { Peak HR } \\
(\mathrm{bpm})\end{array}$ \\
\hline $3^{\circ}$ & $35.8 \pm 10.4$ & $856.9 \pm 195.1$ & $1225.8 \pm 337.6$ & $12.7 \pm 3.0$ & $128.9 \pm 23.3$ \\
$13^{\circ}$ & $31.7 \pm 6.7$ & $788.5 \pm 178.1$ & $1051.4 \pm 277.2^{*}$ & $11.8 \pm 2.8$ & $116.2 \pm 21.0$ \\
\hline
\end{tabular}

$* \mathrm{p}<0.05$

Table 4. Comparison of physiological responses between the two backrest angles during wheelchair propulsion

\begin{tabular}{llllll}
\hline angle & $\mathrm{R}(\mathrm{f} / \mathrm{min})$ & $\begin{array}{l}\mathrm{Vo} 2 \\
(\mathrm{ml} / \mathrm{min})\end{array}$ & $\begin{array}{l}\mathrm{Vco} 2 \\
(\mathrm{ml} / \mathrm{min})\end{array}$ & $\begin{array}{l}\mathrm{Vo} 2 / \mathrm{kg} \\
(\mathrm{ml} / \mathrm{kg} / \mathrm{min})\end{array}$ & $\begin{array}{l}\mathrm{HR} \\
(\mathrm{bpm})\end{array}$ \\
\hline $3^{\circ}$ & $30.0 \pm 9.0$ & $697.1 \pm 160.5$ & $1019.0 \pm 288.6$ & $10.4 \pm 2.3$ & $118.7 \pm 20.9$ \\
$13^{\circ}$ & $25.3 \pm 6.0^{*}$ & $654.4 \pm 146.3^{*}$ & $874.9 \pm 228.3^{*}$ & $9.8 \pm 2.4$ & $107.7 \pm 20.1^{*}$ \\
\hline
\end{tabular}

$* \mathrm{p}<0.05$

his own control with a 1-to-3 day rest period between each experiment.

Subjects sat in a wheelchair for a period of at least three minutes and were then instructed to maintain a speed of 60 $\mathrm{m} / \mathrm{min}$. After a one minute warm-up, subjects propelled the hand $\mathrm{rim}$ at $60 \mathrm{~m} / \mathrm{min}$ for ten minutes. All measurements were recorded every two minutes.

All analyses were performed using SPSS for Windows version 12.0. Data in the two experimental conditions are expressed as mean $\pm \mathrm{SD}$. The differences between backrest angles $\left(3^{\circ} / 13^{\circ}\right)$ for cardiopulmonary function were analyzed using the independent t-test. An alpha level of 0.05 was used as the criterion of statistical significance.

\section{RESULTS}

$\mathrm{Rf}, \mathrm{HR}$ and $\mathrm{VCO}_{2}$ at rest at the backrest angle of $3^{\circ}$ were not significantly different from that at $13^{\circ}$, but $\mathrm{VO}_{2}$ and $\mathrm{VO}_{2} /$ $\mathrm{kg}$ were significantly different between $3^{\circ}$ and $13^{\circ}(\mathrm{p}<0.05)$ (Table 2). The mean value of peak $\mathrm{VCO}_{2}$ was $1,225.8 \mathrm{~mL} /$ min at $3^{\circ}$ and $1,051.4 \mathrm{~mL} / \mathrm{min}$ at $13^{\circ}$, a significantly lower level at $13^{\circ}(\mathrm{p}<0.05)$. However, the mean values of peak $\mathrm{Rf}, \mathrm{VO}_{2}, \mathrm{VO}_{2} / \mathrm{kg}$ and $\mathrm{HR}$ showed no significant differences between the angles of backrest (Table 3). $\mathrm{VO}_{2} / \mathrm{kg}$ during the wheelchair propulsion showed no significant difference between the angles of backrest. Rf (30.0 f/min), $\mathrm{VO}_{2}$ (697.1 $\mathrm{mL} / \mathrm{min}), \mathrm{VCO}_{2}(1,019.0 \mathrm{~mL} / \mathrm{min}), \mathrm{HR}(118.7 \mathrm{bpm})$ in wheelchair propulsion at $3^{\circ}$ were significantly lower than Rf $(25.3 \mathrm{f} / \mathrm{min}), \mathrm{VO}_{2}(654.4 \mathrm{~mL} / \mathrm{min}), \mathrm{VCO}_{2}(874.9 \mathrm{~mL} /$ min) and HR $(107.7 \mathrm{bpm})$ at $13^{\circ}(\mathrm{p}<0.05)$ (Table 4$)$.

\section{DISCUSSION}

Most studies on cardiopulmonary function and wheelchair propulsion have focused on the methods of wheelchair propulsion and how to use a wheelchair. Because wheelchair 
propulsion times did not exceed one minute, they did not provide an accurate evaluation of wheelchair propulsion in daily life, 5 .

The purpose of this study was to measure cardiopulmonary function with changes in backrest angle in wheelchair propulsion. The main focus of cardiopulmonary exercise stress is HR, cardiac output etc., and performance of practical functions affected by the posture of body. In addition, important decision factors in the ventilation ability are the amount of maximum oxygen inhalation and the heartbeat 7 . In this study, only $\mathrm{VO}_{2}$ showed a difference when the backrest angle was changed. Rf, $\mathrm{HR}, \mathrm{VCO}_{2}, \mathrm{VO}_{2} /$ $\mathrm{kg}$ showed no significant differences between the resting period. In general, resting inspiration and expiration occur 10-25 times/min, but respiration can rise up to 40-45 times/ min during physical activities 8 . The results of the present study were similar to the results of previous studies, in that the average $\mathrm{Rf}$ was 20 times/min in the resting period and 35 times/min during peak exercise.

As the backrest angle increased from $3^{\circ}$ to $13^{\circ}, \mathrm{Rf}, \mathrm{VO}_{2}$, $\mathrm{VCO}_{2}$, and HR showed a tendency to decrease. Yune and Byun reported similar results indicating that $\mathrm{Vo} 2$ is lower in the supine position than in standing. In a previous study, while the cardiac output was decreased from that of supine in the head up posture, because of decreasing stroke volume and increasing heart rate, cardiac output was increased by increasing stroke volume in the head down posture 10 . Takahashi et al. 1 reported that Vo2 and anaerobic threshold are influenced by exercise position. The results of their study showed that when the backrest angle was inclined from 20 to 60 degrees, $\mathrm{HR}$ significantly decreased. $\mathrm{VO}_{2}$ and $\mathrm{VCO}_{2}$ also tended to decrease, but not significantly. These results differ from those of the present study. We consider the reason for the difference in the results is that the rear wheel axis of the reclining wheelchair used in this study was moved further back than that of a regular wheelchair.

In particular, HR measurement is very simple and even errors in the measurement of 30 seconds as low as $1-2 \%$ appears; a single measure for the prediction of workload and energy consumption has been recommend for higher accuracy 12 . For the peak values, there were no significant differences except for $\mathrm{VCO}_{2}$ at the different backrest angles. However, as the study of Kusano et al. reported, in a comparison of cerebral palsy and normal adults, the peak $\mathrm{HR}, \mathrm{VE}$, etc. were different and work efficiency (PWC) was as poor as $50 \%$ of normal subjects. In this study, however, we did not compare the relationship between the backrest angle and PWC, because it was not measured.

In conclusion, a $13^{\circ}$ wheelchair backrest angle provided lesser cardiopulmonary workload than the basic angle $\left(3^{\circ}\right)$. Therefore, a training program for good seating and posture needs to be provided. Further study of the backrest angle of wheelchairs will be needed to determine optimal efficiency of cardiopulmonary capacity.

\section{REFERENCES}

1) Chae SY: A study on cardiopulmonary Characteristics by change of backrest angle during manual wheelchair propulsion. Unpublished a master's thesis, Daegu Univ, 2005.

2) Park WH: Cardiopulmonary exercise testing: basis of the physiology. Tuberc Respir Dis, 2003, 54: 589-595.

3) Kusano S, Iwasaki Y, Tobinatsu Y, et al.: Cardiorespiratory endurance and work efficiency of people with cerebral palsy measured using an arm ergometer. J Phys Ther Sci, 2001, 13: 49-52. [CrossRef]

4) Ohtsuki K, Watanabe S: Gender differences in circulatory response measured by the double product break-point method. J Phys Ther Sci, 2007, 19: 189-195. CrossRef

5) Keyser RE, Rodgers MM, Gardner RE, et al.: Oxygen uptake during peak graded exercise and single stage fatigue tests of wheelchair propulsion in manual wheelchair users and the able-bodied. Arch Phys Med Rehabil, 1999, 80: 1288-1292. [Medline] CrossRef

6) Song JY: Relationship between maximal oxygen uptake on arm power, lean arm volume and grip strength in paraplegic subjects. Unpublished a master's thesis, Kyounghee Univ, 2001.

7) Kim KJ: Cardiorespiratory Adaptation to Exercise. Kor Soci Sports Medi, Clinical course book, 1999: 15-19.

8) Brooks GA, Fahey TD: Exercise physiology: Human bioenergetics and its applications. New York: John-Wiley \& Sons Inc, 1984.

9) Yune SH, Byun JH: The cardiopulmonary responses on postural change and intensity of exercise. Chungnam Medi J, 1994, 21: 85-92.

10) Ko SK, Hwang SK, Kim DW, et al.: Responses of the cardiac function during postural changes by tilt table. Kor J Phys Educ, 1997, 36: 213-223.

11) Takahashi T, Yamada S, Tanabe K, et al.: Cardiopulmonary responses at various angles of cycle backrest inclination. J Jpn Phys Ther Assoc, 1999, 2: 31-36. [CrossRef

12) Malhotra MS, Ramswany SS, Ray SN, et al.: Minute ventilation as a measure of energy expenditure during exercise. J Appl Physiol, 1962, 17: $775-777$. 